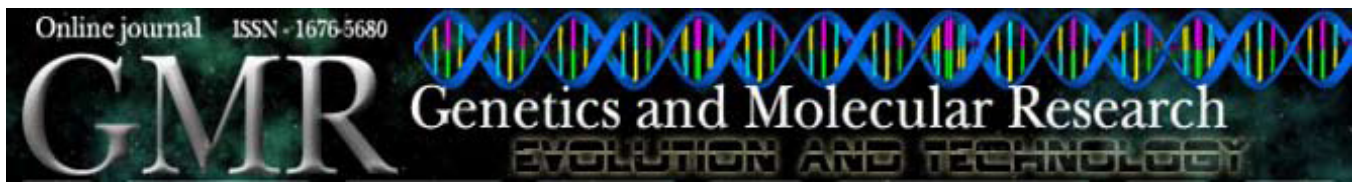

\title{
Mitotic behavior in root tips of Brachiaria genotypes with meiotic chromosome elimination during microsporogenesis
}

\author{
M.F. Felismino ${ }^{1}$, N. Silva ${ }^{1}$, M.S. Pagliarini ${ }^{1}$ and C.B. Valle $^{2}$ \\ ${ }^{1}$ Departamento de Biologia Celular e Genética, \\ Universidade Estadual de Maringá, Maringá, PR, Brasil \\ ${ }^{2}$ Embrapa Gado de Corte, Campo Grande, MS, Brasil \\ Corresponding author: M.S. Pagliarini \\ E-mail: mspagliarini@uem.br
}

Genet. Mol. Res. 7 (2): 336-341 (2008)

Received December 10, 2007

Accepted January 15, 2008

Published April 15, 2008

\begin{abstract}
Three accessions of Brachiaria brizantha, three of $B$. humidicola, and two interspecific hybrids between $B$. ruziziensis and $B$. brizantha were analyzed with regard to their mitotic behavior in root tips. All these genotypes revealed chromosome elimination or lack of chromosome affinity in previous analyses of microsporogenesis. Analyses of root tips showed a normal mitotic division in all accessions and hybrids, reinforcing the notion that the genetic control of meiosis is totally independent of that of mitosis. The implications of these findings for the Brachiaria breeding program are discussed.
\end{abstract}

Key words: Brachiaria; Chromosome elimination; Mitosis; Meiosis 


\section{INTRODUCTION}

Cell division requires an array of complicated processes that must be executed in a spatially and sequentially controlled manner (Dewitte and Murray, 2003). The basic mechanism of mitotic cell cycle control is highly conserved among eukaryotes (Burssens et al., 1998). Progression through the cell cycle boundaries is dependent upon specific serine/threonine kinases, generally referred to as cyclin-dependent kinases, whose activity is modulated by phosphorylation/dephosphorylation events and by their association with regulatory subunits called cyclins (Shaul et al., 1996). The mitotic cell cycle encompasses four sequential ordered stages $-G_{1}, G_{2}, S$, and $M$. The first gap $\left(G_{1}\right.$ phase intercedes between the previous mitosis (M) and the entry into the next replication of DNA (S phase), whereas the second gap $\left(G_{2}\right)$ separates the $S$ phase from the subsequent $M$ phase.

Cell cycle regulation differs in each type of organism, suggesting a fine genetic control. Cell cycle regulatory genes have been identified in several plant species (Staiger and Doonan, 1993; Jacobs, 1995; Assaad et al., 1997; Huntley and Murray, 1999). Meiosis, on the other hand, involves a combination of sequential events that result in four reduced gametes in all sexually reproducing organisms. Many meiotic genes have been reported and isolated in animals and plants (Baker et al., 1976; Golubovskaya, 1979, 1989; Shwarzacher, 2003). Although both the mitotic cell cycle and meiosis are genetically controlled, their control is independent, so that a mutation affecting the mitotic cell cycle does not necessarily affect the meiotic process and vice versa.

Cytogenetic analyses recently performed on the meiotic behavior of several accessions and interspecific hybrids of Brachiaria revealed chromosome elimination or lack of genome affinity during microsporogenesis (Risso-Pascotto et al., 2004, 2006a; Mendes et al., 2006; Mendes-Bonato et al., 2006a). Brachiaria is a genus of tropical grasses of African origin, introduced to Brazil only in the second half of the last century, but it changed beef cattle production in the country, placing Brazil as the second largest producer and first exporter of beef in the world. This study analyzed the chromosome behavior during mitosis in these genotypes to compare with the chromosome behavior observed during meiosis.

\section{MATERIAL AND METHODS}

Three accessions of Brachiaria brizantha (B176, B183, and B222), three of $B$. humidicola (H03, H30, and $\mathrm{H} 42$ ), and two interspecific hybrids between B. ruziziensis and B. brizantha (HB19 and HB40) were analyzed with regard to their mitotic behavior in root tips. Roots were collected from plants grown in pots in greenhouse and fixed in ethanol:acetic acid $(3: 1, \mathrm{v} / \mathrm{v})$ for $24 \mathrm{~h}$. Afterward, they were transferred to $70 \%$ alcohol and stored under refrigeration at $4^{\circ} \mathrm{C}$ until use. Prior to chromosome staining using Feulgen technique, root tips were hydrolyzed in $1 \mathrm{~N} \mathrm{HCl}$ at $60^{\circ} \mathrm{C}$ for $10 \mathrm{~min}$. After squashing, roots were stained with Schiff's reagent for $45 \mathrm{~min}$, and then, macerated in a drop of $45 \%$ acetic acid. Images were photographed with Kodak Imagelink - HQ, ISO 25 in black and white film. Table 1 presents the number of cells analyzed for each mitotic phase per genotype. 


\section{RESULTS AND DISCUSSION}

The mitotic behavior in root tips of accessions and hybrids was completely normal (Table 1) as illustrated in Figure 1. Precocious chromosome migration to the poles, laggard chromosomes, micronuclei, or lack of genome affinity was never observed.

\begin{tabular}{|c|c|c|c|c|c|c|c|c|}
\hline \multirow[t]{2}{*}{ Genotype } & \multirow[t]{2}{*}{ Accession } & \multirow{2}{*}{$\begin{array}{l}\text { Collection site in Africa } \\
\text { (Origin/suborigin) }\end{array}$} & \multicolumn{4}{|c|}{ Mitotic phase } & \multirow{2}{*}{$\begin{array}{l}\text { No. of cells } \\
\text { analyzed }\end{array}$} & \multirow{2}{*}{$\begin{array}{c}\% \text { of abnormal } \\
\text { cells }\end{array}$} \\
\hline & & & PM & $\mathrm{M}$ & $\mathrm{A}$ & $\mathrm{T}$ & & \\
\hline \multirow{3}{*}{ B. brizantha } & B176 & Zimbabwe/Bindura & 24 & 74 & 48 & 55 & 201 & 0 \\
\hline & B183 & Ruanda/Kibungo & 3 & 13 & 13 & 7 & 36 & 0 \\
\hline & B222 & Ethiopia/Kaffa & 52 & 51 & 19 & 25 & 147 & 0 \\
\hline \multirow[t]{3}{*}{ B. humidicola } & H03 & Ethiopia/Sidamo & 13 & 10 & 8 & 10 & 41 & 0 \\
\hline & $\mathrm{H} 30$ & Zimbabwe/Hwange & 8 & 9 & 3 & 8 & 28 & 0 \\
\hline & $\mathrm{H} 42$ & Zimbabwe/Goromonzi & 41 & 78 & 47 & 43 & 209 & 0 \\
\hline \multirow[t]{2}{*}{ Hybrids } & HB19 & - & 64 & 369 & 322 & 190 & 945 & 0 \\
\hline & HB40 & - & 48 & 389 & 164 & 147 & 748 & 0 \\
\hline
\end{tabular}

PM: pro-metaphase; M: metaphase; A: anaphase; T: telophase.

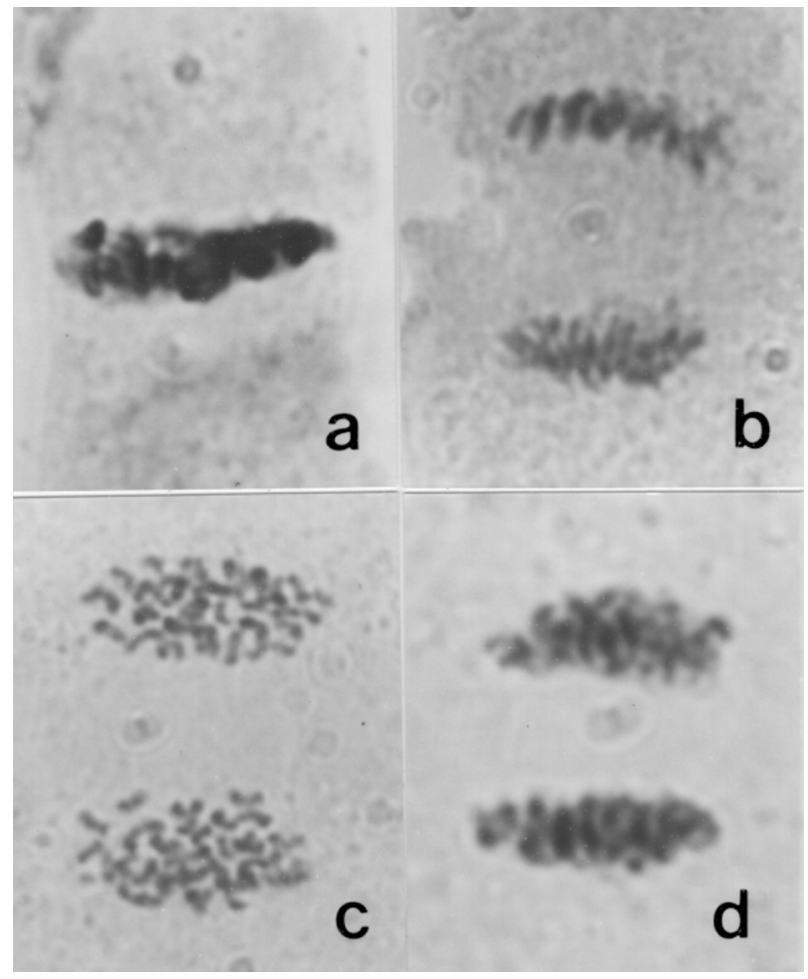

Figure 1. Aspects of normal mitosis in root tips of the Brachiaria hybrid HB40 $(2 n=4 x=36)$. a. Metaphase. b. Anaphase. c. Early telophase. d. Telophase (Magnification: 1000X). 
The main objective of this investigation was to contrast the mitotic and the meiotic behavior in genotypes that presented chromosome elimination or lack of genome affinity during microsporogenesis detected in a previous cytogenetic analysis. The accessions B183 and B222 of B. brizantha (Mendes et al., 2006), the accessions H03, H30, and $\mathrm{H} 42$ of B. humidicola (Boldrini KR, unpublished data) and the hybrid HB40 (Risso-Pascotto et al., 2004) showed chromosome elimination during microsporogenesis. Chromosome elimination was found to be caused by asynchronous meiotic rhythm, i.e., the parental genomes did not take the same time in each meiotic phase, thus the laggard genome was always eliminated from the main telophase nuclei. Chromosome elimination occurred in natural accessions of $B$. brizantha and B. humidicola collected in the African savannas in the middle 1980s and maintained in the field at the Embrapa Beef Cattle Brachiaria germplasm collection, suggesting they are recent allopolyploids. B183 and B222 are pentaploid $(2 \mathrm{n}=5 \mathrm{x}=45)$, derived from $\mathrm{x}=9$, the most common basic chromosome number in the genus Brachiaria (Basappa et al., 1987; Valle and Savidan, 1996; Bernini and Marin-Morales, 2001; Utsunomiya et al., 2005; Mendes-Bonato et al., 2002, 2006b). In these accessions, nine univalents were eliminated by asynchronous meiotic rhythm (Mendes et al., 2006). In the B. $h u$ midicola accessions (H03, H30, and H42), meiotic behavior was similar, also suggesting recent allopolyploidization. However, H03 and H30 accessions are heptaploid $(2 \mathrm{n}=7 \mathrm{x}=42)$ and H42 is nonaploid $(2 \mathrm{n}=9 \mathrm{x}=54)$ (Boldrini $\mathrm{KR}$, unpublished data), derived from $\mathrm{x}=6$, a new basic chromosome number reported for the genus and found in B. dictyoneura (Risso-Pascotto et al., 2006b), a species closely related to B. humidicola. In H03 and H42, six univalents remained behind in relation to the other genome during microsporogenesis and were eliminated; however, in H30, 12 univalents behaved as laggards and were eliminated. The same meiotic behavior was also found in the interspecific triploid hybrid HB40 $(2 n=3 x=27)$ resulting from a cross between a sexual diploid accession of $B$. ruziziensis $(2 \mathrm{n}=2 \mathrm{x}=18)$ and an apomictic tetraploid accession of $B$. brizantha $(2 \mathrm{n}=4 \mathrm{x}=36)$, as pollen donor. In this hybrid, the nine univalent chromosomes of $B$. ruziziensis were eliminated also by asynchronous meiotic rhythm (Risso-Pascotto et al., 2004).

In the accession B176 of $B$. brizantha, meiotic behavior was distinct. This accession is a hexaploid $(2 \mathrm{n}=6 \mathrm{x}=54)$, derived from $\mathrm{x}=9$ (Risso-Pascotto et al., 2006a). In this accession, chromosomes were arranged in two metaphase plates in the first meiotic division. In anaphase I, only nine univalents migrated from each plate to the opposite pole in an angle to form a typical tripolar spindle and, therefore, a restitutional nucleus. The remainder of the chromosomes stayed on the metaphase plate in the first division. After cytokinesis, the restitutional nucleus was eliminated as a microcyte, and the second division proceeded normally for the remainder of the genome. This hexaploid accession could have originated from the chromosome doubling of a triploid derived from species that did not display the same behavior for spindle organization.

In the tetraploid $(2 \mathrm{n}=4 \mathrm{x}=36)$ interspecific hybrid HB19, the meiotic behavior of $B$. ruziziensis and $B$. brizantha genomes was typical of a lack of genome affinity (MendesBonato et al., 2006a). In the first meiotic division of this hybrid, the nine bivalents of $B$. $r u$ ziziensis organized their metaphase plate while the nine bivalents of $B$. brizantha organized a distinct metaphase plate, both in the same cytoplasm. Each chromosome set segregated in its own spindle in anaphase I, forming four telophase nuclei.

This anomalous chromosome behavior observed during microsporogenesis in these accessions and hybrids was not detected during mitosis, reinforcing the notion that the genetic control of meiosis and mitosis is totally independent. Chromosome elimination in mitosis has been widely documented in interspecific hybrids in the early mitosis of embryo development. 
The well-analyzed examples were crosses between Hordeum vulgare and H. bulbosum (Davies, 1974) and crosses between other Hordeum species (Jorgensen and Bothmer, 1988; Linde-Laursen and Bothmer, 1993). Other examples of somatic chromosome elimination in interspecific hybrids have been observed in Nicotiana (Gupta, 1969) and Solanum (Clulow et al., 1991).

Chromosome elimination in interspecific hybrids is a powerful tool in breeding programs. Differential chromosome elimination has facilitated the production of additional lines, while total elimination of one genome permits the formation of haploids. In the genus Brachiaria, the majority of species are polyploidy, mainly tetraploid (Valle and Savidan, 1996; Penteado et al., 2000; Utsunomiya et al., 2005; Mendes-Bonato et al., 2002, 2006a) and polyploidy is closely associated with apomixis (Valle and Savidan, 1996). The embryo emerges from a nucellus somatic cell, containing only the maternal genome. However, apomixis is pseudogamic in this genus, i.e., for seed formation, a viable male gamete needs to fertilize the secondary nucleus of the embryo sac restoring the chromosome proportion found in sexual plants ( $3 n$ endosperm: $2 n$ embryo) for correct endosperm development. Until now, only tetraploid accessions with few meiotic abnormalities have been used as male genitors in the hybridization program. Accessions with other ploidy levels have been generally discarded from the Brachiaria breeding program. From the present investigation and considering the species cited, it is suggested that chromosome elimination in Brachiaria occurs only in meiosis, independent of the ploidy level. Thus, the somatic tissues of these plants are homogeneous in their chromosome constitution since chromosome elimination does not seem to occur in mitosis. It is possible that an accession with chromosome elimination during microsporogenesis, but with a good agronomic trait as a forage grass, and independent of its ploidy level, could be used to create a new cultivar without affecting its overall somatic performance. A crucial condition for the new cultivar to be adopted, however, is good seed production, and that may require adequate behavior during meiosis to assure seed fill.

\section{ACKNOWLEDGMENTS}

The authors are grateful to UNIPASTO for financial support.

\section{REFERENCES}

Assaad FF, Mayer U, Lukowitz W and Jürgens G (1997). Cytokinesis in somatic plant cells. Plant Physiol. Biochem. 35 : 177-184.

Baker BS, Carpenter AT, Esposito MS, Esposito RE, et al. (1976). The genetic control of meiosis. Annu. Rev. Genet. 10: 53-134.

Basappa GP, Muniyamma M and Chinnappa CC (1987). An investigation of chromosome numbers in the genus Brachiaria (Poaceae: Paniceae) in relation to morphology and taxonomy. Can. J. Bot. 65: 2297-2309.

Bernini C and Marin-Morales MA (2001). Karyotype analysis in Brachiaria (Poaceae) species. Cytobios 104: 157-171.

Burssens S, Van Montagu M and Inze D (1998). The cell cycle in Arabidopsis. Plant Physiol. Biochem. 36: 9-19.

Clulow SA, Wilkinson MJ, Waugh R, Baird E, et al. (1991). Cytological and molecular observations on Solanum phurejainduced dihaploid potatoes. Theor. Appl. Genet. 82: 545-551.

Davies DR (1974). Chromosome elimination in interspecific hybrids. Heredity 32: 267-270.

Dewitte W and Murray JA (2003). The plant cell cycle. Annu. Rev. Plant. Biol. 54: 235-264.

Golubovskaya IN (1979). Genetic control of meiosis. Int. Rev. Cytol. 58: 247-290.

Golubovskaya IN (1989). Meiosis in maize: mei genes and conception of genetic control of meiosis. Adv. Genet. 26: 149-192.

Gupta SB (1969). Duration of mitotic cycle and regulation of DNA replication in Nicotiana plumbaginifolia and a hybrid derivative of N. tabacum showing chromosome instability. Can. J. Genet. Cytol. 11: 133-142. 
Huntley RP and Murray JA (1999). The plant cell cycle. Curr. Opin. Plant Biol. 2: 440-446.

Jacobs TW (1995). Cell cycle control. Annu. Rev. Plant Physiol. Plant Mol. Biol. 46: 317-339.

Jorgensen RB and Bothmer R (1988). Haploids of Hordeum vulgare and H. marinum from crosses between the two species. Hereditas 108: 207-212.

Linde-Laursen I and Bothmer R (1993). Aberrant meiotic divisions in a Hordeum lechleri x H. vulgare hybrid. Hereditas 118: $145-153$.

Mendes DV, Boldrini KR, Mendes-Bonato AB, Pagliarini MS, et al. (2006). Cytological evidence of natural hybridization in Brachiaria brizantha Stapf (Gramineae). Bot. J. Linn. Soc. 150: 441-446.

Mendes-Bonato AB, Pagliarini MS, Forli F, Valle CB, et al. (2002). Chromosome numbers and microsporogenesis in Brachiaria brizantha (Gramineae). Euphytica 125: 419-425.

Mendes-Bonato AB, Risso-Pascotto C, Pagliarini MS and Valle CB (2006a). Chromosome number and meiotic behaviour in Brachiaria jubata (Gramineae). J. Genet. 85: 83-87.

Mendes-Bonato AB, Risso-Pascotto C, Pagliarini MS and Valle CB (2006b). Cytogenetic evidence for genome elimination during microsporogenesis in interspecific hybrid between Brachiaria ruziziensis and Brachiaria brizantha (Poaceae). Genet. Mol. Biol. 29: 711-714.

Penteado MIO, Santos ACM, Rodrigues IF, Valle CB, et al. (2000). Determinação de poliploidia e avaliação da quantidade de DNA total em diferentes espécies de gênero Brachiaria. Boletim de Pesquisa, 11. Embrapa Gado de Corte, Campo Grande.

Risso-Pascotto C, Pagliarini MS, Borges do V and Jank L (2004). Asynchronous meiotic rhythm as the cause of selective chromosome elimination in an interspecific Brachiaria hybrid. Plant Cell Rep. 22: 945-950.

Risso-Pascotto C, Mendes DV, Silva N, Pagliarini MS, et al. (2006a). Evidence of allopolyploidy in Brachiaria brizantha (Poaceae: Paniceae) through chromosome arrangement at metaphase plate during microsporogenesis. Genet. Mol. Res. 5: 797-803

Risso-Pascotto C, Pagliarini MS and Valle CB (2006b). A new basic chromosome number for the genus Brachiaria (Trin.) Griseb. (Poaceae: Panicoideae: Paniceae). Genet. Res. Crop Evol. 53: 7-10.

Schwarzacher T (2003). Meiosis, recombination and chromosomes: a review of gene isolation and fluorescent in situ hybridization data in plants. J. Exp. Bot. 54: 11-23.

Shaul O, Montagu MV and Inzé D (1996). Regulation of cell division in Arabidopsis. Crit. Rev. Plant Sci. 15: 97-112.

Staiger C and Doonan J (1993). Cell division in plants. Curr. Opin. Cell Biol. 5: 226-231.

Utsunomiya KS, Pagliarini MS and do Valle CB (2005). Microsporogenesis in tetraploid accessions of Brachiaria nigropedata (Ficalho \& Hiern) Stapf (Gramineae). Biocell 29: 295-301.

Valle CB and Savidan Y (1996). Genetics, cytogenetics, and reproductive biology of Brachiaria. In: Brachiaria: Biology, Agronomy, and Improvement (Miles JW, Maas BL and Valle CB, eds.). Centro Internacional de Agricultura Tropical - CIAT/Empresa Brasileira de Pesquisa Agropecuária - EMBRAPA. CIAT, Colômbia, 147-163. 